\title{
Taloudellisen tuottavuuden tutkimisesta
}

\section{SAKARI LÄHDEMÄKI}

Taloudellinen tuottavuus on merkittävä tekijä, joka määrittää elintasoamme ja yleisemmin millaista elämämme on. Omalla sukupolvellani ja sitä nuoremmilla ei ole samanlaista konkreettista kokemusta siitä, miten elintason nousu muuttaa yhteiskuntaa ja sen asukkaiden elämää kuin vanhemmilla sukupolvilla. Synnyin ennen 1990-luvun alun lamaa ja olin niin nuori sen aikana, ettei minulla ole siitä merkittäviä muistoja. Myöskään siitä millaista elämä oli esimerkiksi 1960- ja 1970-luvuilla ei ole kokemusta. Kun on elänyt koko elämänsä sellaista aikakautta, jossa elintaso on ollut verrattain korkea, sitä kenties liian helposti tulee sorruttua siihen, että pitää yhteiskunnan palvelutasoa ja elintasoa itsestään selvinä. Elintason nousua Suomessa ja laajemmin maailmassa selittää taloudellisen tuottavuuden kasvu. Siis yksinkertaisesti se, että yhden tunnin työ on tuottanut enemmän ja enemmän tuotteita ja palveluja kuin aiemmin.

Taloustieteessä tuottavuus ja tuottavuuskasvu ovat laajasti tutkittuja aiheita (ks. esim. Syversson 2011). Ei liene väärin sanoa, että tuottavuus on keskeisimpiä tutkimusaiheita. Tätä luonnollisesti selittää se, että se on hyvin keskeinen yhteiskuntia ja yhteiskuntien elintasoa määrittävä tekijä. Todettakoon, että elintaso, jota mitataan vaikkapa väestönmäärään suhteutetulla bruttokansatuotteella (BKT), ja hyvinvointi ovat jokseenkin eri asioita, mutta aika yleisesti hyväksytään ajatus, että elintaso mahdollistaa tai ainakin kulkee käsi kädessä myös korkeamman hyvinvoinnin kanssa.

Taloustieteessä tuottavuuden kasvua selitetään talouskasvua mallintavien kasvumallien ja niiden taustalla olevan kasvuteorian avulla. Modernia talouskasvua kuvaavat mallit tyypillisesti implikoivat, että pitkällä aikavälillä teknologisen kehityksen kasvu määrittää tuottavuuden kasvua (ks. esim. Aghion ja Howitt 2009). Nykyään enenevissä määrin ollaan kiinnostuneita siitä mitkä tekijät vaikuttavat teknologisen kehityksen kasvuvauhtiin ja ovatko ne sellaisia, joihin voidaan jotenkin poliittisilla valinnoilla vaikuttaa (ks. esim. Aghion ja Howitt 2009). Esimerkkinä mainittakoon koulutukseen liittyvät päätökset ja se voidaanko tutkimus- ja tuotekehitystoimintaa tehostaa tai lisätä tukitoimin.

Ottamatta näihin tässä kantaa on hyvä tuoda tämä yhteys esiin. Pitkän aikavälin tuottavuuskasvua voidaan pitää aika etäisenä asiana, sillä poliittisessa päätöksenteossa keskitytään paljolti nykyisyyteen, mutta sillä kuitenkin on selviä yhtymäkohtia niihin poliittisiin valintoihin, joita nytkin mietitään. Vaikuttaa myös siltä, että pitkän aikavälin tuottavuuskasvu on viime vuosina Suomessa ja muualla länsimaissa saanut enemmän huomiota, koska länsimaissa tuottavuuskasvu on hiipunut verrattuna siihen, mitä se pitkään oli (ks. lisää esim. Moss, Nunn ja Shambaugh 2020).

Keskeinen tutkimuksen tekemiseen vaikuttava asia, joka on muuttunut vuosien saatossa, on tilastoidun tiedon määrä. Yleisesti ottaen kaikenlainen data, jota voidaan hyödyntää tutkimuksen 
teossa, on lisääntynyt huomattavasti. Tämä koskee niin mikro- kuin makrotaloudellistakin tutkimusta. Aineistojen parempi kattavuus ja saatavuus ovat mahdollistaneet aiempaa laajemman ja luotettavamman empiirisen taloustieteellisen tutkimuksen tekemisen. Toinen merkittävä asia on ekonometristen menetelmien kehittyminen. Toisin sanoen niiden tilastollisten menetelmien kehittyminen, joilla taloutta tutkitaan empiirisesti. On todettava myös, että tähän liittyen kasvanut laskentakapasiteetti, kehittyneet tilasto-ohjelmat ja ohjelmointimahdollisuudet ovat luoneet empiiriselle tieteen teolle aiempaa selvästi paremmat valmiudet.

Ajattelen että tieteen luonteeseen kuuluu tietynlainen halu tehdä asiat paremmin tai tarkemmin kuin aiemmin. Tästä syystä tieteen sisällä kehitetään alati menetelmiä, jotka tuottavat aiempaa luotettavampia tuloksia. Sama intohimo saavuttaa aiempaa tarkempia ja varmempia tuloksia ajaa myös laajempien tilastojen keruuseen ja käyttöön. Samaan prosessiin kuuluu myös se, että tutkijat toistavat jo tehtyjä tutkimuksia ja haastavat vallalla olevia käsityksiä, tuloksia ja teorioita. Usein tietysti aiemmat tulokset ovat päteviä ja kestävät tämän tarkastelun, mutta toisinaan uusin aineistoin ja menetelmin tehdyt tutkimukset haastavat aiempia tuloksia. Nämä uudet tarkastelut kuitenkin nojaavat tai ainakin vertautuvat aina siihen työhön, joka on jo aiemmin tehty.

Väitöskirjani koostuu kolmesta itsenäisestä tutkimusartikkelista. Väitöskirjan erillisiä artikkeleja yhdistävä teema on taloudellinen tuottavuus niin kuin teoksen nimikin, Essays on Economic Productivity, kertoo.

Väitöskirjani ensimmäisessä artikkelissa tarkastelen kansainvälisen aineiston pohjalta sitä, lähentyvätkö maiden taloudelliset tuottavuudet toisiaan. Aineistossa on tiedot käytännössä kaikkien maailman maiden bruttokansantuotteesta ja työllisyydestä ainakin joltain ajanjaksolta. Tämän artikkelin tulokset vahvistavat jo aiemmin havaittuja tuloksia, mutta tarjoavat myös uusia tuloksia tästä aiheesta. Yksi keskeinen havainto on, että vuoden 2000 jälkeen kaikkien maiden tuottavuuksien hajonta on alkanut supistua. Tämän voi tulkita niin, että köyhempien maiden tuottavuudet ovat lähentyneet rikkaimpien maiden tuottavuustasoa. Kehityksen jatkuessa samankaltaisena pitkään, köyhempien maiden tuottavuuskasvu oletettavasti nostaa myös näiden maiden väestön elintasoa.

Voi tietysti ajatella, että tällaisella tutkimuksella on lähinnä tiedettä itseään hyödyttävä vaikutus tai korkeintaan yleissivistystä lisäävä yhteiskunnallinen merkitys. Mutta mietittäessä esimerkiksi investointipäätöksiä, joita suuret kansainväliset yritykset tekevät, on keskeistä, miten ItäEuroopan tai Aasian ajatellaan kehittyvän seuraavana vuosikymmenenä. Tiedolla, jota tällainen tarkastelu tarjoaa, voikin olla paljon yhteiskunnallista merkitystä. Tämäntyyppinen tutkimus ei ehkä kuitenkaan anna mitään yksinkertaista suoraa suositusta, miten vaikkapa Suomen pitäisi talouspolitiikkaansa harjoittaa.

Taloustieteessä tyypillisesti arvostetaan tutkimuksia, joiden perusteella voidaan antaa suoraan joku selkeä politiikkasuositus. Usein poliittiset päätökset kuitenkin liittyvät kysymyksiin, joihin ei löydy suoraa vastausta tutkimuksista. Ja toisaalta tutkimusta, josta tällainen tulos saataisiin, ei käytännössä voida toteuttaa ainakaan annetussa aikataulussa. Tällöin on varmasti paikallaan, että meillä on ajankohtaisin tieteen tarjoama sivistys ja taustatieto, jonka pohjalta näitä päätöksiä tehdään. 
Väitöskirjan toisessa artikkelissa tutkimme sitä, miten eri maiden maantieteelliset erityispiirteet ovat yhteydessä taloudelliseen tuottavuuteen. Voidaan ajatella, että lähtökohtaisesti talouden pohja on pitkälti muovattavissa. Esimerkiksi instituutiot, kuten lainsäädäntö, on viime kädessä ihmisten päätettävissä. Tässä artikkelissa ajatuksena on päinvastaisesti tarkastella selittävätkö sellaiset tekijät maiden välisiä tuottavuuseroja, jotka ovat pitkälti annettuja. Aika usein, kun verrataan maiden välisiä talouseroja, näihin tekijöihin vedotaan, vaikka aivan selvää näyttöä väitteiden tueksi ei aina olisikaan. Jokainen on varmaan jossain yhteydessä kuullut nämä fraasit: "norjalaiset ja öljy", "Suomi on vihreän kullan maan" ja "Venäjä on suuri luonnonvara-aitta”.

Artikkelin tulokset viittaavat siihen, että maantieteelliset tekijät eivät juurikaan selittäisi maiden välisiä tuottavuuseroja, mutta ne saattavat muokata sitä taloudellista rakennetta, joka on tuottavuuden taustalla. Tulosten valossa näyttäisi esimerkiksi siltä, että syrjäisen sijainnin maissa tutkimus- ja tuotekehitystoiminta on intensiivisempää. Yleisesti ottaen tulokset lisäävät ymmärrystä siitä miksi taloudet ovat erilaisia, mutta tulokset jättävät kuitenkin osin tulkinnanvaraiseksi, miten tulosten pohjalta tulisi reagoida tai voiko talouspolitiikalla vaikuttaa tutkimuksessa ilmenneisiin eroihin.

Mikro- ja makrotaloudellisten tuottavuuksien tarkastelut ovat tietysti suorassa yhteydessä toisiinsa. BKT:n laskemisessa huomioidaan kaikkien Suomessa toimivien yritysten arvonlisäys. Se, mitä tapahtuu yritystasolla, vaikuttaa suoraan koko taloutta kuvaaviin mittareihin. Väitöskirjani kolmas artikkeli eroaa kahdesta aiemmasta siten, että siinä tarkastellaan tuottavuutta mikrotasolla ja erityisesti sitä, miten yksityistäminen vaikutti yksityistettyjen yritysten toimipaikkojen tuottavuuteen.

Kolmas artikkeli eroaa kahdesta aiemmasta siinäkin, että tässä voidaan soveltaa sellaista menetelmää, joka on kehitetty kausaalivaikutusten arviointiin. Viime vuosina taloustieteessä on entistä enemmän alettu käyttää menetelmiä, joiden avulla voidaan tuottaa luotettavampia arvioita kausaalivaikutuksesta (ks. Currier, Kleven ja Zwiers 2020). Se, että joidenkin asioiden välillä on jokin yhteys tai korrelaatio, ei vielä tarkoita, että toinen näistä aiheuttaisi muutoksen toisessa. Näillä menetelmillä voidaan tarkastella nimenomaisesti sitä, kuinka suuren muutoksen jokin tekijä aiheuttaa toisessa. Näiden menetelmien laajentunut käyttö on sen taustalla, että empiirisen taloustieteen yhteydessä on sanottu tapahtuneen credibility revolution eli vapaasti suomennettuna "vallankumous luotettavuudessa" (ks. Angrist ja Pischke 2010).

Ajateltaessa tutkimuksen relevanssia politiikanteon kannalta tällaiset tutkimukset tarjoavat ainakin periaatteessa päätöksentekijöille paljon luotettavamman arvion siitä, mitä tapahtuu, jos tehdään jokin muutos talouspolitiikassa. Sanon periaatteessa siksi, että usein nämä menetelmät ovat aika vaativia tutkimusasetelman ja aineiston suhteen ja näihinkin menetelmiin, kuten kaikkeen tutkimukseen, liittyy omia ongelmiaan. Yleensä tämäntyyppiset tutkimukset tarkastelevat kuitenkin suoraan, miten jokin tietty harjoitettu politiikka vaikuttaa tiettyihin tulemiin ja siksikin ne tarjoavat usein politiikanharjoittajalle käyttökelpoisia tuloksia.

Artikkelin tulosten mukaan näyttäisi siltä, että yksityistäminen nosti tuottavuutta. Käytetyn menetelmän ja aineiston vuoksi pitäisin tätä tulosta melko vahvana. Tutkimuksen tuloksia tulkittaessa tulee kuitenkin huomata, että tässä rajoituttiin tarkastelemaan yrityksiä, jotka nähtiin valtion sijoituksina tai investointeja ja jotka toimivat kilpailullisilla markkinoilla. Tutkimuksessa ei tarkasteltu lainkaan valtion monopoleja. Siksi tuloksia ei voida suoraan yleistää koskemaan 
monopoleja, vaikka tutkimus muutoin tukee sitä ajatusta, että yksityinen omistajuus on tehokkaampaa kuin julkinen.

Väitöskirjan artikkelit tutkivat tuottavuutta eri näkökulmista ja eri menetelmin. Länsimaiden hidastunut tuottavuuskasvu ja globaali talouskehitys tekevät tuottavuuden tutkimisesta mielenkiintoista ja tärkeää. Artikkelien mukaan köyhien ja rikkaiden maiden väliset tuottavuuserot ovat alkaneet supistua, maantieteelliset tekijät saattavat selittää osittain sitä miksi kehittyneidenkin maiden välillä on kuitenkin tuottavuuseroja, ja yksityistäminen näyttäisi nostavan sellaisten valtion yhtiöiden tuottavuutta, jotka toimivat kilpailullisilla markkinoilla.

Väitöskirja "Essays on Economic Productivity" tarkastettiin Turun yliopistossa 5.3.2021. Vastaväittäjänä toimi professori Mika Maliranta Jyväskylän yliopistosta ja kustoksena professori Janne Tukiainen Turun yliopistosta.

\section{LÄHTEET}

Aghion, Philippe ja Howitt, Peter. 2009. The Economics of Growth. Cambridge, MA: MIT Press.

Angrist, Joshua ja Pischke, Jörn-Steffan. 2010. The credibility revolution in empirical economics: How better research design is taking the con out of econometrics. Journal of economic perspectives, 24:2, $3-30$.

Currie, Janet, Kleven, Henrik ja Zwiers, Esmée. 2020. Technology and big data are changing economics: Mining text to track methods. AEA Papers and Proceedings 110, 42-48.

Moss, Emily, Nunn, Ryan, ja Shambaugh, Jay. 2020. The slowdown in productivity growth and policies that can restore it. The Hamilton Project, Brookings Institution, Washington, DC.

Syversson, Chad. 2011. What determines productivity? Journal of Economic Literature 49:2, 326-365.

\section{KIRJOITTAJATIEDOT}

\section{SAKARI LÄHDEMÄKI}

KTT, vanhempi tutkija

Palkansaajien tutkimuslaitos

sakari.lahdemaki@labour.fi 